\title{
Germination and Growth of Citrus: Trifoliate Orange (Poncirus trifoliata (L.) in Different Organic Substrates
}

\author{
Birkha Bahadur Tamang (Corresponding author) \\ Agriculture Research and Development Center, Wengkhar, Mongar, Bhutan \\ Tel: +975-17973160, E-mail: bbtamang@moaf.gov.bt \\ Sonam Tashi \\ College of Natural Resource, Royal University of Bhutan \\ Tel: +975-02-17768276,+975-02-376251,E-mail: stashi@cnr.rub.edu.bt
}

Received: July 8, 2019

Accepted: August 20, 2019

Published: August 21, 2019

doi:10.5296/jas.v7i3.15035

URL: https://doi.org/10.5296/jas.v7i3.15035

\begin{abstract}
This study was carried out to explore the effect of different organic substrates on germination and growth of trifoliate (Poncirus trifoliata (L.) Raf.). The experiment was conducted at the Agriculture Research and Development Sub-center (ARDSC), Mithun, Tsirang from July 2014 to March 2015. This experiment was arranged in a randomized complete block design. Each treatment was replicated four times and there were seven treatments. Six different combinations of organic substrates were used. Germination of the seed was done in plug trays of $60 \mathrm{~cm}$ x $45 \mathrm{~cm}$ with 60 plug holes and effect on germination was assessed until 30 days after sowing (DAS). After transplanting the seedlings in poly pots $(12 \mathrm{~cm} \times 6 \mathrm{~cm})$, assessment on growth parameters was done until 210 days after transplanting (DAT). T5: biogas slurry + topsoil + sand + leaf mold + sawdust + rice husk (2: 1: $1: 1: 1: 1)$ had water holding capacity of $62.7 \%$, air-filled porosity of $8.1 \%$, OM of $6.3 \%$, maximum seed emergence rate of $37.4 \%$, maximum germination index (7.6) and maximum germination percentage of 91.3\%. Besides, stem height of $15 \mathrm{~cm}$, stem girth of $3.6 \mathrm{~mm}$, taproot length of $35.6 \mathrm{~cm}$, the number of secondary roots of 61 , secondary root spread of $21.4 \mathrm{~cm}$ and seedling mortality rate of zero was significantly $(p<.01)$ different from other treatments.
\end{abstract}

Keywords: days after sowing, days after transplanting, germination, growth, organic substrates and trifoliate 


\section{Macrothink}

\section{Introduction}

Citrus includes species from six closely related genera, Citrus, Poncirus (trifoliate orange), Fortunella (kumquat), Eremocitrus (desert lime), Microcitrus (Australian wild lime), and Clymenia, which all belong to the Rutaceae family (Swingle and Reece, 1967).

In Bhutan mandarin is one of the major cash crops with $40 \%$ of Bhutan's population dependent on mandarins for food and income (Vergnani, 2013). Over the years due to various pests and diseases production has been declining. To overcome production loss, the need for resistant and suitable rootstock (RT) has become a priority. Producing healthy RTs depends on the quality and types of medium.

Organic residues such as urban solid wastes, sewage sludge, chicken waste, cattle manure, paper waste, pruning waste, spent mushroom and even green wastes after proper composting, can be used as growth media with very good results (Ostos et al., 2008). Availability and use of commercial media in Bhutan are still not existent except for hazelnut nursery rising. However, there are many local organic media available. But studies on standardization of media for RT rising has not been conducted so far. Therefore, the present study is aimed at identifying a suitable media mix that can provide a suitable environment and optimum nutrients to the seedlings both during germination and growth.

\section{Materials and Methods}

\subsection{Study Area}

The experiment was conducted from July 2014 to March 2015 at the Agriculture Research and Development Sub-Center (ARDSC), Mithun, under Kikhorthang block, Tsirang district. The site is located at 1483 meters above sea level (masl) between $27^{\circ} 30^{\prime} 11^{\prime \prime} \mathrm{N}$ and $89^{\circ}$ 52 '42"'E.

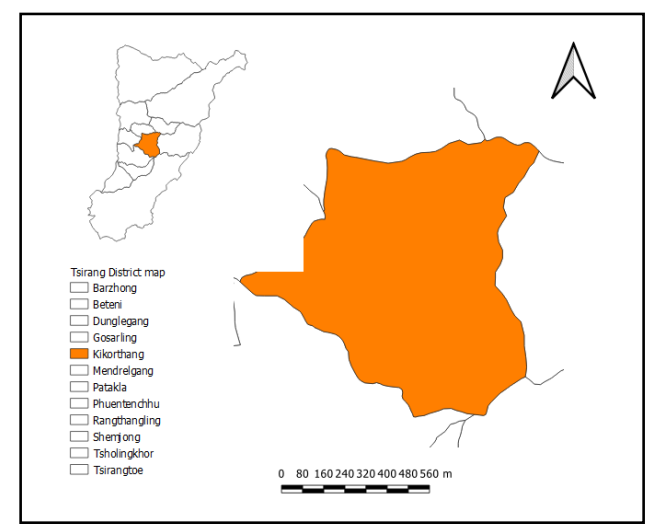

Figure 1. Map of the study site

\subsection{Treatments}

The experiment was conducted in randomized complete block design (RCBD) with seven treatments. The seven treatments were T1(control): top soil + sand + leaf mold + rice husk at $1: 1: 1: 1: 1$ ratio), T2: farm yard manure + top soil + sand + leaf mold + saw dust + rice 
husk at $2: 1: 1: 1: 1: 1$ ratio, T3: poultry manure + top soil + sand + leaf mold + saw dust + rice husk at $2: 1: 1: 1: 1: 1$ ratio, T4: goat manure + top soil + sand + leaf mold + saw dust + rice husk at $2: 1: 1: 1: 1: 1$ ratio, T5: biogas slurry + top soil + sand + leaf mold + saw dust + rice husk at $2: 1: 1: 1: 1: 1$ ratio, T6: farm yard manure + top soil + sand + leaf mold + saw dust + rice husk at $1: 1: 1: 1: 1: 1$ ratio) and T7: poultry manure + top soil + sand + leaf mold + saw dust + rice husk at $1: 1: 1: 1: 1: 1$ ratio.

\subsection{Growing Media Analysis}

The growing media of each treatment were analyzed for both physical and chemical properties (Table 1). The $\mathrm{pH}$ was determined in water (1:1) by Beckman Zero-Matic $\mathrm{pH}$ meter with a glass electrode using buffers of $\mathrm{pH} 4.0$ and 9.0 standardizing instrument (Method 21a). The organic matter content was determined through loss on ignition method. Total N was determined by Kjeldal method as it was described by Jackson (1962). Available P was extracted using Bray No. 2 extraction solution method as performed by Bray and Kurtz (1945). Available K was determined by extracting calcium chloride using a Segmented Flow Analyzer with a flame photometer.

The physical properties such as porosity and water holding capacity of each of the treatments were determined (Table 1) using air-filled porosity apparatus based on Handreck and Black (2010). Percentage of air-filled porosity (\% AFP) was calculated using the following formula:

$$
\text { Percentage of AFP }=\frac{\mathrm{ml} \text { drained }}{\mathrm{ml} \text { basevolume }} \times \frac{100}{1} \ldots \ldots
$$

Where AFP is for air-filled porosity of medium recorded at a certain period. The total water holding capacity (WHC) was calculated using the following equation:

$$
\text { WHC }=\frac{(\text { tray }+ \text { wetpottingmix })-(\text { tray }+ \text { drypottingmix })}{\text { mlbasevolume }} \times \frac{100}{1} \ldots \ldots
$$

Where WHC means the water holding capacity of medium for a given period of time.

\subsection{Seed Sowing and Germination}

Seven months old seeds that were stored at $4-7{ }^{\circ} \mathrm{C}$ were soaked overnight in tap water and their coats removed. They were then treated with mancozeb solution $(2 \mathrm{~g} / \mathrm{litre})$ for half an hour and washed three to four times with tap water before sowing in plug trays $(60 \mathrm{~cm} \times 45$ $\mathrm{cm}$ ) which were filled with media mixes. After sowing, the seeds were watered immediately. Thereafter, irrigation was carried out at two days' interval until the seedlings attained one month. In each treatment, 60 seeds out of which $35 \%$ (or 25 seeds) from each treatment were randomly tagged for data collection.

Germination of the seeds was assessed for one month. The rate of emergence (RE) for all treatments was calculated following the method of Islam et al. (2009) as shown by the equation: 


$$
\text { Rate of emergence }(\mathrm{RE})=\frac{\text { Number of seedlings emerged } 10 \text { DAS }}{\text { Number of seedlings emerged } 30 \text { DAS }} 100
$$

The germination percentage was calculated as the per cent of germinating seeds from the first germination to 30 days after sowing (DAS). Germination percentage was calculated by dividing the number of germinated seedlings by the number of seeds sown in each treatment and multiplying this by 100 . The germination index (GI) for each treatment was calculated using the following formula prescribed by the anonymous (1983).

$$
\mathrm{GI}=\frac{\text { Number of germinating seeds }}{\text { Days of first count }}+\frac{\text { Number of germinating seeds }}{\text { Days of final or last count }} \ldots \ldots \text {... }
$$

Once the seedlings attained one-month-old, taproot length, length and girth of the shoot were measured using a measuring scale and vernier calipers (model: CD-6" CSX). The taproot length was measured from collar region till the tip of taproot. Likewise, stem length was measured from collar region till the tip of new flush. The girth was recorded at the middle portion of the seedling. Number of secondary roots, number of taproot, number of leaves and polyembryonic seeds were manually counted by taking the seedlings out of the polythene bags.

\subsection{Transplanting of Seedlings}

When the seedlings attained one month in a plug tray, 25 seedlings from each of the treatments having almost the same height were transplanted in $12 \mathrm{~cm} \times 6 \mathrm{~cm}$ polythene bags for assessing growth parameters. Of the total 25 transplanted seedlings in each treatment, $40 \%$ (or 10) seedlings were randomly tagged for data collection.

After transplanting, the data for growth characteristics were recorded once a month up to seven months. The growth parameters include stem height, stem girth and number of seedlings survived. The height of the seedlings was measured using measuring a scale from collar region till the tip of the new flush. The girth was recorded at the middle portion of the seedling stem. Seedling survival percent was calculated using the following formula:

$$
\text { Survival percent }=\frac{\text { Total survived seedlings }}{\text { Total transplanted seedlings }} \times 100 \ldots \ldots
$$

At the end of 210 days after transplanting (DAT) or (seven months), 40\% (or 10) of the seedlings from each treatment were uprooted for recording the taproot length, a number of secondary roots and secondary root spread. The root length was measured from collar region till the tip of taproot. The roots that have come from the taproot were counted manually and recorded as a secondary root. The secondary root spread was measured across middle of taproot where the length of secondary roots was the highest.

Data on temperature and humidity inside the polythene house was recorded using data loggerTinytagPlus 2, TGP-4500. Data on seed germination (up to one month) and seedling growth 


\section{Macrothink

(up to seven months) were compiled and analyzed using the statistical software, Statistics 8 . Means, coefficient of variance and standard deviation of the effect of different substrates on germination and growth were analyzed. The significance level was at 0.05 .

\section{Results and Discussion}

\subsection{Physical and Chemical Characteristics of Substrates}

Maximum water holding capacity (82.6\%) (Table 1) was found in T3 and minimum (59.9\%) in T2. T3 had the maximum water holding capacity because the sawdust was used as bedding for poultry. Substrates with total water holding capacities greater than $35 \%$ are the most satisfactory for general nursery cropping (Krucker, 2003).

Highest AFP was in T3 with $11.5 \%$ followed by T7 at 10.6\%, while T1 (control) had the least AFP of $4.7 \%$. AFP was highest in $\mathrm{T} 3$ and $\mathrm{T} 7$ because of larger particle size of the sawdust these treatments. The $\mathrm{pH}$ of treatments analyzed before the experiment for all treatments ranged from 6.4 to 7.7 (Table 1). T2 and T7 had the highest of 7.7 each followed by T3 at 7.5.

Incomplete decomposition of media mixes in T2, T7 and T3 could have been one of the reasons for the high $\mathrm{pH}$. Minimum $\mathrm{pH}$ was in $\mathrm{T} 5$ at 6.4 and $\mathrm{T} 4$ at 6.5 . T5 had maximum organic matter (OM) of $6.3 \%$ followed by T4 (5.2\%). Minimum OM content was recorded in T6 at $2.5 \%$ followed by T7 at $2.9 \%$. High OM content in T5 may have been because of the higher amount of biogas slurry waste and leaf mould. Warnars and Openoorth (2014) have also recorded up to $7 \% \mathrm{OM}$ in medium containing biogas slurry waste.

The $\mathrm{N}$ content of different media mixes ranged between $0.4 \mathrm{mg} / \mathrm{kg}$ (T1, T5, T6 and T7) to 0.7 $\mathrm{mg} / \mathrm{kg}$ (T3). Similarly, Akhtar et al. (2013) had found N content in poultry manure as high as 2.1\%. Available P ranged between $311 \mathrm{mg} / \mathrm{kg}$ for T6 and $752.8 \mathrm{mg} / \mathrm{kg}$ for T2 with others in between. Amongst the treatments, the available K ranged between $33 \mathrm{mg} / \mathrm{kg}$ (T5) and 921 $\mathrm{mg} / \mathrm{kg}$ (T6). According to the guidelines of the National Soil Service Center (NSSC) (2009), the level of available $\mathrm{P}$ and $\mathrm{K}$ were considered very high in all the treatments. This could be because organic substrates such as rice husk and leaf mould used in the media mixes contain higher $\mathrm{P}$ and $\mathrm{K}$. 
Table 1. Physical and chemical properties of treatments before the experiment

\begin{tabular}{|c|c|c|c|c|c|c|c|}
\hline \multirow[t]{3}{*}{ TRT } & \multicolumn{2}{|c|}{$\%$} & \multirow{3}{*}{$\mathrm{OM}$} & \multirow{3}{*}{$\begin{array}{c}\mathrm{pH} \\
\left(\mathrm{H}_{2} \mathrm{O}\right)\end{array}$} & \multirow{3}{*}{$\begin{array}{c}\% \\
\mathrm{~N} \\
\text { (Kjeldahl) }\end{array}$} & \multicolumn{2}{|c|}{$\mathrm{mg} / \mathrm{kg}$} \\
\hline & TWC & AFP & & & & $\mathrm{P}$ avail & K avail \\
\hline & \multicolumn{2}{|c|}{ (Handreck \& Black) } & & & & Bray & $\left(\mathrm{CaCl}_{2}\right.$ extract $)$ \\
\hline T1 & 62.5 & 4.7 & 3.4 & 6.9 & 0.4 & 645.9 & 591.4 \\
\hline $\mathrm{T} 2$ & 59.9 & 6.3 & 4.3 & 7.7 & 0.6 & 752.8 & 253.3 \\
\hline $\mathrm{T} 3$ & 82.6 & 11.5 & 4.9 & 7.5 & 0.7 & 414.2 & 152.7 \\
\hline $\mathrm{T} 4$ & 63.3 & 6.3 & 5.2 & 6.5 & 0.5 & 572 & 80.3 \\
\hline $\mathrm{T} 5$ & 62.7 & 8.1 & 6.3 & 6.4 & 0.4 & 610.7 & 33.3 \\
\hline T6 & 62.1 & 5.6 & 2.5 & 7.1 & 0.4 & 311.1 & 921.1 \\
\hline $\mathrm{T} 7$ & 75.1 & 10.6 & 2.9 & 7.7 & 0.4 & 367.6 & 872.7 \\
\hline
\end{tabular}

\subsection{Germination Parameter}

\subsubsection{Seed Germination at 10 DAS, 30 DAS and percentage Germination}

The per cent of seed germination between the treatments was very significant $(p<.01)$ (Table 2). A maximum number of $20.5 \pm 9.9$ seeds germinated in T5 and a minimum of $0.0 \pm 00$ in T3 within first 10 DAS. At 30 DAS, maximum of $54.8 \pm 4.9$ and $54.8 \pm 3.0$ seeds were in T2 and T5 respectively. T7 had minimum of $29.8 \pm 4.3$ seeds germinated followed by $35.5 \pm 8.3$ in T3. The results indicate that the germination of seeds was earlier in T5 compared to other treatments. This was because, in T5, the water holding capacity and air-filled porosity were optimal, which could have supplied adequate moisture and oxygen to the seeds as well as maintained relatively warmer temperature.

Germination per cent of seeds was different in each treatment (Table 2). Maximum percentage $(91.3 \%$ each) of seeds germinated in T2 and T5 which had water holding capacities of $59.9 \%$ and $62.7 \%$ respectively. The results indicated that treatments having WHC nearer to $60 \%$ had higher seeds germination percent. Air filled porosity of the aforementioned treatments were recorded at $7.9 \%$ and $8.3 \%$, respectively.

Under greenhouse condition, Carvalho and Silva (2013) obtained 88\% germination in trifoliate seeds that were stored for seven months at $5^{\circ} \mathrm{C}$. In a similar study, Oliveira et al. (2003) observed better germination percentage of trifoliate seeds in spring (95.6\%) compared to winter $(83.6 \%)$ when sown in commercial media. The minimal germination per cent of 49.6\% was recorded in T7. The germination in this treatment was affected by higher WHC and AFP. In T3 and T7 incidence of moulds was observed, which caused the seeds to decay that affected germination. This could be because the treatments had higher $(82.6 \%$ and $75.1 \%)$ per cent of WHC and AFP. A substrate needs to be non- toxic, free of molds with adequate aeration and moisture for germination of seeds (Justice, 1972).

Other reasons for maximal seed germination in T5 could have been because of high OM 
content which increases the water and air holding a capacity of the medium improving the water utilization capacity of the seeds. OM matter acts as glue for media aggregates and source of nutrient for seedlings and high content of organic matter in the media decreases the fluctuation of temperature Bhardwaj (2014). Besides, T5 had finer particles that enhanced the contact of seeds to the media.

Table 2. Number of seeds germinated at 10 DAS, 30 DAS and per cent germination

\begin{tabular}{lccc}
\hline TRT & 10 DAS & 30 DAS & \% germination \\
\hline T1 (Control) & $7 \pm 3.2^{\mathrm{bc}}$ & $50.0 \pm 5.6^{\mathrm{a}}$ & 83.3 \\
T2 & $9.0 \pm 1.4^{\mathrm{bc}}$ & $54.8 \pm 4.9^{\mathrm{a}}$ & 91.3 \\
T3 & $0.0 \pm 0.0^{\mathrm{c}}$ & $35.5 \pm 8.3^{\mathrm{b}}$ & 59.2 \\
T4 & $3.75 \pm 3.1^{\mathrm{bc}}$ & $48.3 \pm 7.4^{\mathrm{a}}$ & 80.1 \\
T5 & $20.5 \pm 9.9^{\mathrm{a}}$ & $54.8 \pm 3.0^{\mathrm{a}}$ & 91.3 \\
T6 & $10.0 \pm 3.74^{\mathrm{b}}$ & $51.5 \pm 4.0^{\mathrm{a}}$ & 85.8 \\
T7 & $0.6 \pm 0.6^{\mathrm{bc}}$ & $29.8 \pm 4.3^{\mathrm{b}}$ & 49.7 \\
\hline CV $(\%)$ & 54.4 & 9.6 & \\
\hline$F$ value & $* *$ & $* *$ & \\
\hline
\end{tabular}

** = Highly significant. The values are means of the effect of treatments on seeds germinated at $10 \mathrm{DAS}$ and $30 \mathrm{DAS}$ and \pm standard deviation of the means. Different superscripts in the same column differ significantly at $p<.01 . n=60$.

\subsection{Growth parameters}

\subsubsection{Rate of Seedling Emergence}

Rate of seedling emergence calculated based on Islam et al. (2009) equation showed that first seedling emergence within 10 days after sowing (DAS) in T5 and last was observed in T3 at 13 DAS. Temperature record of mean minimum $\left(20.6 \pm 1.9^{\circ} \mathrm{C}\right)$ and mean maximum $(45.4 \pm$ $5.3^{\circ} \mathrm{C}$ ) were recorded during that time. Due to optimum WHC and APF of T5, the seed emergence was maximal. In a study by Saeed et al. (2010), citrus seed emergence after 14 DAS under constant temperature of $26^{\circ} \mathrm{C}$. The speed of emergence was maximal (43\%) in T5 and minimal $(1 \%)$ in $\mathrm{T} 2$.

\subsubsection{Stem Height and Girth at the End of 210 DAT}

At the end of 210 DAT, the highest stem length was observed in T5 $(15.4 \mathrm{~cm})$ followed by T4 $(12.4 \mathrm{~cm})$ and T6 $(11.3 \mathrm{~cm})$. Schafer et al. (2008) recorded the highest growth of trifoliate was $15.6 \mathrm{~cm}$ during the growth period of four months. T3 had the least stem length growth $(4.1 \mathrm{~cm})$. Starting from 150 DAT, seedling in T3 showed sign of dieback. This had caused the seedling height to reduce from $5.4 \mathrm{~cm}$ at 90 DAT to $3.5 \mathrm{~cm}$ at 180 DAT. Generally, seedling growth in all the treatments was minimal at 120 to 150 DAT. It was due to low winter temperature $\left(6.8\right.$ to $\left.27.9^{\circ} \mathrm{C}\right)$.

There was a significant effect $(p<0.01)$ of treatments on stem girth (Table 3). T5 had 


\section{Macrothink}

Journal of Agricultural Studies

ISSN 2166-0379

2019, Vol. 7, No. 3

maximal girth from 30 DAT $(1.8 \mathrm{~mm})$ and finally measured $3.6 \mathrm{~mm}$ at the end of 210 DAT. Unlike stem height, stem girth did not decrease in any of the treatments. Minimum stem girth of $1.4 \mathrm{~mm}$ at $30 \mathrm{DAT}$ and $1.9 \mathrm{~mm}$ was recorded in $\mathrm{T} 7$ and $\mathrm{T} 3$, respectively. The poor seedling growth recorded in media with PM in T3 and T7 agrees with the findings of Akthar et al. (2013) who reported the same for Gambeya albida (G. Don) seedlings grown in PM media.

Optimal $\mathrm{N}$ release from $\mathrm{T} 5$ followed by $\mathrm{T} 4$ and $\mathrm{T} 6 \mathrm{had}$ favored seedlings heights to increase faster than other treatments. This statement is in line with the findings of Opheusden et al. (2012) who estimated that bio-slurry decomposes up to $60 \%$ and releases $112 \mathrm{~kg} \mathrm{~N}$ per hectare, whereas the decomposition rate of PM was found to be $56.5 \%$ with $\mathrm{N}$ release of 85 $\mathrm{kg}$ per hectare.

Maximal OM content in T5 followed by T4 enhanced seedling growth and development due to $\mathrm{OM}$ influencing media properties, including the media to supply nutrients, improve aggregation, infiltration and retention of water. Other reason for maximal stem height and girth could be the optimal N content in T5 and T4. As described by Sanchez and Gonzalez (2005), lack or excess of $\mathrm{N}$ can decrease or even damage the growth and yield of crops.

Citrus is acid-loving species and thrives best in media with $\mathrm{pH}$ below neutral. According to Schafer et al. (2008), pH more than 7.0 can have a negative influence on the release of nutrients, thereby jeopardizing plant development. At the same time, the $\mathrm{pH}$ of $\mathrm{T} 5$ was below the neutral point which is suitable for citrus that made availability of nutrients to the seedlings. Besides, the reason for maximum growth attained in T5 which was amended with BGW is that it contains readily available plants nutrients. In agreement to this, Warnars and Openoorth (2014) described BGW as a serious alternative to chemical fertilizers which even contains higher amounts of macro nutrients and micronutrients than FYM. Besides, nitrification ability of BGW was confirmed superior than other organic manures as observed by Desai and Biswas (1945), Acharya (1961) and Chawla (1984). 
Table 3. Effect of treatments on monthly growth rate of stem height after transplanting

\begin{tabular}{lccccccc}
\hline & \multicolumn{7}{c}{ Monthly growth in stem height (cm) } \\
\cline { 2 - 7 } TRT & \multicolumn{7}{c}{ DAT } \\
\cline { 2 - 8 } & 30 & 60 & 90 & 120 & 150 & 180 & 210 \\
\hline T1 & $7.1 \pm 1.2^{\mathrm{c}}$ & $8.8 \pm 2.3^{\mathrm{b}}$ & $9.4 \pm 2.8^{\mathrm{c}}$ & $9.4 \pm 2.5^{\mathrm{c}}$ & $9.4 \pm 3.1^{\mathrm{c}}$ & $9.6 \pm 3.2^{\mathrm{c}}$ & $9.9 \pm 1.7^{\mathrm{c}}$ \\
$\mathrm{T} 2$ & $7.4 \pm 1.2^{\mathrm{c}}$ & $7.6 \pm 1.9^{\mathrm{b}}$ & $7.5 \pm 1.6^{\mathrm{d}}$ & $6.1 \pm 1.8^{\mathrm{d}}$ & $5.5 \pm 1.8^{\mathrm{de}}$ & $4.9 \pm 1.5^{\mathrm{de}}$ & $5.8 \pm 2.2^{\mathrm{d}}$ \\
$\mathrm{T} 3$ & $5.0 \pm 1.0^{\mathrm{d}}$ & $5.2 \pm 1.5^{\mathrm{c}}$ & $5.4 \pm 1.5^{\mathrm{e}}$ & $5.2 \pm 1.4^{\mathrm{d}}$ & $3.9 \pm 2.2^{\mathrm{e}}$ & $3.5 \pm 2.4^{\mathrm{e}}$ & $4.1 \pm 2.1^{\mathrm{d}}$ \\
$\mathrm{T} 4$ & $8.6 \pm 1.4^{\mathrm{ab}}$ & $10.6 \pm 2.2^{\mathrm{a}}$ & $11.1 \pm 2.5^{\mathrm{ab}}$ & $11.2 \pm 1.9^{\mathrm{b}}$ & $11.3 \pm 2.7^{\mathrm{b}}$ & $11.8 \pm 1.9^{\mathrm{b}}$ & $12.4 \pm 1.2^{\mathrm{b}}$ \\
$\mathrm{T} 5$ & $8.7 \pm 1.4^{\mathrm{a}}$ & $10.5 \pm 2.4^{\mathrm{a}}$ & $12.4 \pm 3.5^{\mathrm{a}}$ & $13.2 \pm 3.4^{\mathrm{a}}$ & $13.8 \pm 3.5^{\mathrm{a}}$ & $14.6 \pm 2.9^{\mathrm{a}}$ & $15.4 \pm 2.6^{\mathrm{a}}$ \\
$\mathrm{T} 6$ & $7.8 \pm 1.4^{\mathrm{bc}}$ & $8.9 \pm 1.5^{\mathrm{b}}$ & $9.7 \pm 1.8^{\mathrm{bc}}$ & $10.2 \pm 1.9^{\mathrm{bc}}$ & $10.3 \pm 2.0^{\mathrm{bc}}$ & $10.3 \pm 2.0^{\mathrm{bc}}$ & $11.3 \pm 1.5^{\mathrm{b}}$ \\
T7 & $4.9 \pm 1.2^{\mathrm{d}}$ & $5.9 \pm 1.5^{\mathrm{c}}$ & $6.5 \pm 1.8^{\mathrm{de}}$ & $6.6 \pm 1.9^{\mathrm{d}}$ & $5.7 \pm 1.9^{\mathrm{d}}$ & $5.4 \pm 2.8^{\mathrm{d}}$ & $5.7 \pm 1.7^{\mathrm{e}}$ \\
\hline CV $(\%)$ & 17.6 & 22.7 & 24.6 & 23.9 & 27.9 & 27.3 & 20.3 \\
\hline$F$ value & $* *$ & $* *$ & $* *$ & $* *$ & $* *$ & $* *$ & $* *$ \\
\hline
\end{tabular}

$* *=$ Highly significant. The values are means of the effect of treatments on stem height \pm standard deviation of the means. Different superscripts in the same column differ significantly at $p<.01$.

Table 4. Effect of treatments on monthly growth rate of stem girth after transplanting

\begin{tabular}{lccccccc}
\hline & \multicolumn{7}{c}{ Monthly growth in stem girth $(\mathrm{mm})$} \\
\cline { 2 - 8 } TRT & \multicolumn{7}{c}{ DAT } \\
\cline { 2 - 8 } & 30 & 60 & 90 & 120 & 150 & 180 & 210 \\
\hline T1 & $1.5 \pm 0.2^{\mathrm{bc}}$ & $1.9 \pm 0.1^{\mathrm{a}}$ & $2.1 \pm 0.2^{\mathrm{ab}}$ & $2.3 \pm 0.3^{\mathrm{ab}}$ & $2.4 \pm 0.3^{\mathrm{ab}}$ & $2.6 \pm 0.4^{\mathrm{b}}$ & $2.7 \pm 0.3^{\mathrm{bc}}$ \\
$\mathrm{T} 2$ & $1.7 \pm 0.3^{\mathrm{ab}}$ & $1.9 \pm 0.4^{\mathrm{a}}$ & $2.1 \pm 0.2^{\mathrm{b}}$ & $2.1 \pm 0.3^{\mathrm{b}}$ & $2.2 \pm 0.3^{\mathrm{b}}$ & $2.2 \pm 0.6^{\mathrm{c}}$ & $2.4 \pm 0.7^{\mathrm{cd}}$ \\
$\mathrm{T} 3$ & $1.5 \pm 0.3^{\mathrm{bc}}$ & $1.6 \pm 0.3^{\mathrm{b}}$ & $1.8 \pm 0.3^{\mathrm{c}}$ & $1.8 \pm 0.4^{\mathrm{c}}$ & $1.8 \pm 0.6^{\mathrm{c}}$ & $1.9 \pm 0.8^{\mathrm{d}}$ & $2.1 \pm 1.0^{\mathrm{de}}$ \\
$\mathrm{T} 4$ & $1.8 \pm 0.3^{\mathrm{a}}$ & $1.9 \pm 0.3^{\mathrm{a}}$ & $2.1 \pm 0.3^{\mathrm{ab}}$ & $2.3 \pm 0.3^{\mathrm{a}}$ & $2.4 \pm 0.3^{\mathrm{a}}$ & $2.6 \pm 0.4^{\mathrm{bc}}$ & $2.8 \pm 0.2^{\mathrm{b}}$ \\
$\mathrm{T} 5$ & $1.8 \pm 0.2^{\mathrm{a}}$ & $1.9 \pm 0.2^{\mathrm{a}}$ & $2.2 \pm 0.4^{\mathrm{a}}$ & $2.4 \pm 0.3^{\mathrm{a}}$ & $2.6 \pm 0.4^{\mathrm{a}}$ & $3.2 \pm 0.5^{\mathrm{a}}$ & $3.6 \pm 0.3^{\mathrm{a}}$ \\
$\mathrm{T} 6$ & $1.8 \pm 0.3^{\mathrm{a}}$ & $1.9 \pm 0.3^{\mathrm{a}}$ & $2.1 \pm 0.3^{\mathrm{ab}}$ & $2.4 \pm 0.4^{\mathrm{a}}$ & $2.6 \pm 0.4^{\mathrm{a}}$ & $2.8 \pm 0.5^{\mathrm{b}}$ & $2.9 \pm 0.3^{\mathrm{b}}$ \\
$\mathrm{T} 7$ & $1.4 \pm 0.2^{\mathrm{c}}$ & $1.6 \pm 0.2^{\mathrm{b}}$ & $1.8 \pm 0.2^{\mathrm{c}}$ & $1.8 \pm 0.4^{\mathrm{c}}$ & $1.9 \pm 0.4^{\mathrm{c}}$ & $1.9 \pm 0.5^{\mathrm{d}}$ & $1.9 \pm 0.5^{\mathrm{e}}$ \\
\hline $\mathrm{CV}(\%)$ & 16.1 & 13.9 & 13.1 & 15.1 & 17 & 20.8 & 19.7 \\
\hline$F$ value & $* *$ & $* *$ & $* *$ & $* *$ & $* *$ & $* *$ & $* *$ \\
\hline
\end{tabular}

$* *=$ Highly significant. The values are means of the effect of treatments on stem girth \pm standard deviation of the means. Different superscripts in the same column differ significantly at $p<.01$.

\subsection{Root Evaluated at the End of 210 DAT}

Treatment 5 had significantly higher taproot length $(35 \mathrm{~cm})$ and a number of secondary roots $(61 \mathrm{~cm})$ compared to all other treatments (Table 5). This was followed by T4 with length of taproot (LTR) of $29 \mathrm{~cm}$ and a number of secondary roots (NSR) at $45 \mathrm{~cm}$. While LTR and 
NSR of T1 and T6 were significantly higher than those of other remaining three treatments.

While the root diameter of T5 and T6 were not significantly different from each other they were significantly higher than the secondary root spread (SRS) of all other treatments. The SRS of T1 (control) was the smallest.

Poerwanto et al. (1989) found that low temperature $\left(15^{\circ} \mathrm{C}\right)$ inhibited root development but high temperature $\left(35^{\circ} \mathrm{C}\right)$ stimulated root development of trifoliate orange seedlings, as compared with the optimum temperature $\left(25^{\circ} \mathrm{C}\right)$. Similarly, Wiltbank et al. (1995) observed that limited root growth of citrus plants at a temperature below $20^{\circ} \mathrm{C}$ and no root growth at a temperature below 12 or $14^{\circ} \mathrm{C}$.

Table 5. Effect of treatments on root parameters at the end of 210 DAT

\begin{tabular}{lccc}
\hline TRT & LTR $(\mathrm{cm})$ & SRS $(\mathrm{cm})$ & NSR \\
\hline T1 (Control) & $25.3 \pm 3.5^{\mathrm{c}}$ & $13.6 \pm 3.5^{\mathrm{c}}$ & $32.4 \pm 6.6^{\mathrm{c}}$ \\
T2 & $14.5 \pm 2.4^{\mathrm{d}}$ & $8.1 \pm 1.1^{\mathrm{de}}$ & $15.7 \pm 4.2^{\mathrm{d}}$ \\
T3 & $12.9 \pm 2.4^{\mathrm{d}}$ & $7.1 \pm 0.9^{\mathrm{e}}$ & $12.3 \pm 2.7^{\mathrm{d}}$ \\
T4 & $29.8 \pm 4.8^{\mathrm{b}}$ & $18.6 \pm 2.8^{\mathrm{b}}$ & $45.2 \pm 5.8^{\mathrm{b}}$ \\
T5 & $35.6 \pm 2.8^{\mathrm{a}}$ & $21.4 \pm 3.4^{\mathrm{a}}$ & $61.2 \pm 3.3^{\mathrm{a}}$ \\
T6 & $24.8 \pm 3.5^{\mathrm{c}}$ & $21.9 \pm 3.2^{\mathrm{a}}$ & $31.0 \pm 3.7^{\mathrm{c}}$ \\
T7 & $13.8 \pm 2.1^{\mathrm{d}}$ & $10.6 \pm 1.6^{\mathrm{d}}$ & $14.8 \pm 4.7^{\mathrm{d}}$ \\
\hline CV $(\%)$ & 13.7 & 18.2 & 15.1 \\
\hline$F$ value & $* *$ & $* *$ & $* *$ \\
\hline
\end{tabular}

** = Highly significant. The values are means of the effect of treatments on tap root length, number of secondary roots and root dimension \pm standard deviation of the means. Different superscripts in the same column differ significantly at $p<.01$. (LTR = Tap root length, NSR = Number of secondary roots and SRS = Secondary root spread)

\subsection{Dry Matter (DM) and Root Shoot Ratio}

The effect of treatments on both root and shoot DM of the seedlings were different (Figure 2). Both shoot $(45.2 \%)$ and root $(38.7 \%)$ were highest in T5 compared to other treatments. Minimum of the shoot (32.7\%) and the root (23.5\%) DM was observed in T7.

This could be because during the fermentation process of biogas slurry, due to reducing $\mathrm{C}: \mathrm{N}$ ratio some carbon may have been removed thus increasing the fertilizing effect of the media. Besides, the $\mathrm{pH}$ of the media mix was below the neutral point which is favorable for the growth and development of citrus. Other properties of the media mix such as water holding capacity, air-filled porosity and available macro nutrients were at the optimum level that favored the accumulation of dry matter in a root and shoot in T5. Harris (1992) also pointed out that except for injury to the roots; a reduction in the root-shoot ratio is almost always in response to more favorable growing conditions. 


\section{Macrothink}

On the other hand, the minimum DM in T7 and lowest root-shoot ratio (0.6) in T3 could be because these treatments were amended with PM. As a result the $\mathrm{pH}$ of the treatments was high that caused unavailability of required nutrients for the seedlings. Besides, occurrence of die back in the seedlings required more energy/ food to recover resulting in decreased DM.

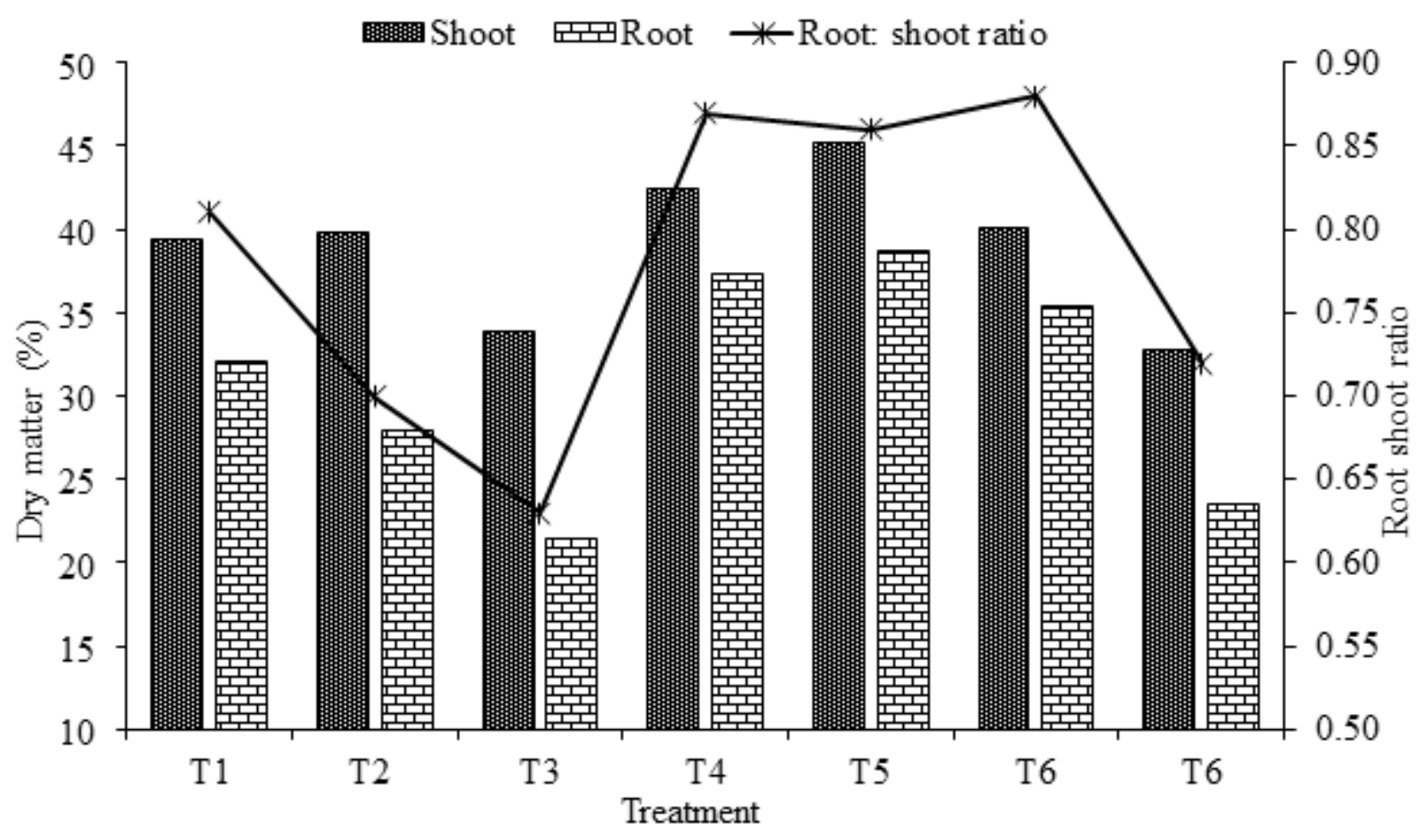

Figure 2. Effect of treatments on DM and root-shoot ratio at 210 DAT

\subsection{Seedling Mortality at the End of 210 DAT}

The mortality rate was recorded highest at $45 \%$ in $\mathrm{T} 2$ and lowest at $0 \%$ in other treatments except T1, T4, T5 and T7 (Table 6). The mortality of seedlings was high in treatments amended with PM and FYM. It was because the $\mathrm{pH}$ of these two organic manures was more alkaline than other treatments, which may have injured the rooting system or blocked the nutrient availability to the seedlings.

$\mathrm{N}$ release pattern from PM and FYM keep increasing (Ipinmoroti, 2013). This trend could have caused toxicity to the plant and ultimate death. The higher $\mathrm{pH}$ observed for the organic materials was probably influenced by the mineralization and subsequent release of nutrients from the organic matter. So, since higher $\mathrm{pH}$ is not suitable for citrus, the growth and development in those treatments was very poor. 


\section{Macrothink}

Table 6. Effect of treatments on seedling mortality rate at 210 DAT

\begin{tabular}{lccc}
\hline TRT & Mortality (number) & Mortality (\%) & Survival (\%) \\
\hline T1 (Control) & 0 & 0 & 100 \\
T2 & 17 & 45 & 55 \\
T3 & 18 & 42.5 & 47.5 \\
T4 & 0 & 0 & 100 \\
T5 & 0 & 0 & 100 \\
T6 & 1 & 2.5 & 97.5 \\
T7 & 0 & 0 & 100 \\
\hline
\end{tabular}

$n=40$

\section{Conclusion}

Seed germination and seedling growth are affected by several factors, including biotic and abiotic. The latter group includes climate (temperature, light quality and intensity, and moisture availability) and chemical factors (nutrient levels, $\mathrm{pH}$ ). The medium and its composition or mix also affects seed germination and seedling growth. Therefore, the choice and proportion of substrate mix play a vital role in attaining good germination and growth.

Lack of quality citrus rootstock in Bhutan is still a major constraint in citrus production industry. The result of the study reveal that use of substrate mix amended with biogas slurry waste as a source nutrient source had significant effect on germination of trifoliate seeds. Though germination result in control treatment did not differ much from other treatments, the seedlings had started to show yellowing during growth assessment. Growth of seedlings was better in T5 followed by T4 until 210 DAT which were amended with bio-gas slurry waste and goat manure, respectively. Poultry manure as nutrient amendment is not advisable.

Researches on germination and growth of seeds in different organic substrate mixes are very limited than commercial media mixes. Therefore, further such experiments should be conducted before giving concrete recommendation on choice of organic substrate mixes for the nursery dealers or plant enthusiasts.

\section{Acknowledgement}

We would like to thank Officer In-charge and staff of RNR-RDSC, Mithun, Tsirang for their guidance, support and facilities provided during the study. The merits of success of this study go to hard working and dedicated services of laboratory personals of College of Natural Resources, Lobesa and National Soil Service Center, Thimphu.

\section{References}

Acharya, C. N. (1961). Preparation of Fuel Gas and Manure by Anaerobic Fermentation of Organic Materials. New Delhi, Indian Agriculture Research institute. 
Akhtar, S., Shakeel, S., Mehmoodz, A., Hamid, A., \& Saifz, S. (2013). Comparative Analysis of Animal Manure for Soil Conditioning. Kinnaird College for Women, Environmental Sciences. International Journal of Agronomy and Plant Production, 4(12), 3360-3365.

Anonymous. (1983). Association of Official Seed Analysis (AOSA)-Seed vigor testing handbook. Contribution No. 32 to the handbook on seed testing. Association of Official Seed Analysis. Springfield, IL.

Bhardwaj, R. L. (2014). Effect of growing media on seed germination and seedling growth of Papaya cv, 'Red lady'. African Journal of Plant Science, 8(4), 178-184. https://doi.org/10.5897/AJPS11.265

Bray, R. H., \& Kurtz, L. T. (1945). Determination of total, organic, and available forms of $\begin{array}{llll}\text { phosphorus in } \quad \text { soils. } & \text { Soil } & \text { 39-45.ence, }\end{array}$ https://doi.org/10.1097/00010694-194501000-00006

Carvalho, S. A., \& Silva, L. F. C. (2013). Monitoring the viability of citrus rootstocks seeds stored under refrigeration. Rev. Bras. Fructic, (35), 238-245. https://doi.org/10.1590/S0100-29452013000100027

Chawla, O. P. (1984). Manurial Aspects: Advances in Biogas Technology. New Delhi: ICAR.

Desai, S. V., \& Biswas, S. C. (1945). Manure and Gas Production by Anaerobic Fermentation of Organic Wastes. Indian Farming, (6), 67-78.

Handreck, K. A., \& Black, N. D. (2010). Growing Media for Ornamental Plants and Turf. Randwick, NSW .University of New South Wales Press.

Harris, R. W. (1992). Root-shoot ratios. Department of Environmental Horticulture, University of California, Davis, California. Journal of Arboriculture, 18(1), 39-42.

Hong, T. D., \& Ellis, R. H. (1995). Interspecific variation in seed storage behavior within two genera - Coffee and Citrus. Seed Science and Technology, (23), 165-181.

Ipinmoroti, R. R. (2013). Decomposition and Nutrient Release Pattern of some farm wastes under controlled condition. International Journal of Agriculture and Forestry, 3(4), 185-189. https://doi.org/10.5923/j.ijaf.201304.10.

Islam, A. K, Anuar, N., \& Yaakob, Z. (2009). Effect of genotypes and pre-sowing treatment on seed germination behavior of jatropha. Asian Journal of Plant Science, (8), 433-439. https://doi.org/10.3923/ajps.2009.433.439

Jackson, M. L. (1962). Soil chemical analysis. pp. 263-268. Prentice Hall, New York.

Justice, O. L. (1972). Essentials of seed testing, Seed Biology. pp. 301-370. Academic Press. https://doi.org/10.1016/B978-0-12-395605-7.50011-9

Krucker, M. L. (2003). Root and shoot growth of chrysanthemum in various compost media utilizing overhead and sub-irrigation methods at two fertilizer rates. MS Thesis. Washington State University.

NSSC (2009). A guide to fertilizer recommendation for major crops. Semtokah, Thimphu. pp. 


\section{4-5. National Soil Science Centre.}

Oliveira, R. P., Scivittaro, W. P., \& Radmann, E. B. (2003). Procedimentos para o armazenamento de sementes de Poncirus trifoliata (L.) Raf. Revista Brasileira de Fruticultura. Jaboticabal, 25(3), 461-463. https://doi.org/10.1590/S0100-29452003000300025

Opheusden, A. H. M., Burgt, G. J. H. M., \& Rietberg, P. I. (2012). Decomposition rate of organic fertilizers: effect on yield, nitrogen availability and nitrogen stock in the soil. <http://www.louisbolk.org/downloads/2666.pdf>. Accessed 12 February 2015

Ostos, J. C., Lopez-Harrido, R., Murillo, J. M., \& Lopez, R. (2008). Substitution of peat for municipal solid waste- and sewage sludge-based composts in nursery growing media: Effects on growth and nutrition of the native shrub Pistacia lentiscus L. Biores. Technology, (99), 1793-1800. https://doi.org/10.1016/j.biortech.2007.03.033

Poerwanto, R., Inoue, H., \& Kataoka, I. (1989). Effects of Temperature on the morphology and physiology of trifoliate orange budded with Satsuma mandarin. Faculty of Agriculture, Kagawa University, Miki-Cho, Japan. J. Japan. Society Horticultural Society, 58(2), 267--274. https://doi.org/10.2503/jjshs.58.267

Saeed, M., Dodd, P. B., \& Sohail, L. (2010). Anatomical studies of stems, roots and leaves of selected citrus rootstock varieties in relation to their vigor. Journal of Horticulture and Forestry, 2(4), 87-94.

Sanchez, M., \& Gonzalez, J. L. (2005). The fertilizer value of pig slurry: Values depending on the type of operation. Bioresource Technology, (96), 1117-1123. https://doi.org/10.1016/j.biortech.2004.10.002

Schafer, G., de Souza, P. V. D., Koller, O. C., \& Schwarz, S. F. (2008). Physical and Chemical Properties of Substrates to Cultivate Seedling of Citrus Rootstocks. Communications in Soil Science and Plant Analysis, (39), 1067-1079. https://doi.org/10.1080/00103620801925547

Swingle, W. T., \& Reece, P. C. (1967). The botany of citrus and its wild relatives. The Citrus Industry, (1), 190-430.

Vergnani, L. (2013). Tiny black insect threat to Bhutan citrus. University of Western Sydney.

Warnars, L., \& Oppenoorth, H. (2014). Bio-slurry: A supreme fertilizer- A study on bio-slurry results and uses. pp. 11-13. Deltahage press.

Wiltbank, W. J., Rouse, R. E., \& Khoi (1995). Influence of temperature on citrus rootstock seed emergence. Proc. Fla. State Horticulture Society, (108), 137-139.

\section{Copyright Disclaimer}

Copyright for this article is retained by the author(s), with first publication rights granted to the journal.

This is an open-access article distributed under the terms and conditions of the Creative Commons Attribution license (http://creativecommons.org/licenses/by/4.0/). 